MIECZYSŁAW WRZOSEK (Warszawa)

\title{
DOKUMENTY DOTYCZACE ZAGROŻEŃ SPRAWY POLSKIEJ, POLSKOŚCI I STANU POLSKIEGO POSIADANIA W GALICJI, KRÓLESTWIE POLSKIM I NA KRESACH DAWNEJ RZECZYPOSPOLITEJ (1915-1918)
}

Operacje letniej kampanii wojsk niemieckich na froncie wschodnim, zakończone rozkazem feldmarszałka Pawła von Hindenburga z 25 września 1915 roku i ofensywne działania armii austro-węgierskiej, wstrzymane na tym froncie pod koniec pierwszej dekady października tegoż roku, doprowadzily do opanowania Królestwa Polskiego i znacznych terenów kresowych dawnej Rzeczypospolitej. Wymienione tu wojska dotarły mianowicie po linię Dyneburg - jezioro Narocz - Baranowicze - Pińsk - Czerniowce. Na obszarach Królestwa Polskiego, opuszczonych przez wojska rosyjskie, zaznaczyła się wówczas wyraźna aktywizacja środowisk inteligenckich i ziemiańskich. Stanowiła ona przejaw polskich aspiracji niepodległościowych oraz zatroskania o stan poskiego posiadania głównie na kresowych obszarach dawnej Rzeczypospolitej.

W okresie od 4 do 25 czerwca 1916 r. armie państw centralnych (Niemiec i Austro-Węgier) znalazły się jednak pod naporem wojsk rosyjskich i na obszarach wołyńsko-podolskich były zmuszone do częściowego odwrotu. Ten odwrót wymusiły armie wchodzące w skład wojsk rosyjskiego Frontu Południowo-Zachodniego, a ich działania przeszły do historii jako „ofensywa Brusiłowa". W okresie od 26 czerwca do 10 lipca 1916 r. wojska niemieckie i austro-węgierski zdobyły się jednak na przeprowadzenie lokalnych zwrotów zaczepnych, a potem kontynuowały uporczywe walki obronne. $\mathrm{W}$ ich wyniku zdołały powstrzymać Rosjan na obszarach wołyńskich nad Stochodem, a na terenach podolskich nad Złotą Lipą i Dniestrem.

Część obszarów podolskich i wołyńskich, utraconych latem 1916 roku, wojska niemieckie i austro-węgierskie zajęły ponownie w lipcu 1917 r., czyli 
wówczas, gdy najpierw powstrzymały tak zwaną ofensywę Aleksandra Kiereńskiego, a potem przeszły do ograniczonych działań zaczepnych i w ich wyniku dotarły nad Zbrucz oraz nad Styr. Kolejna faza działań zaczepnych podejmowanych przez wojska niemieckie i austro-węgierskie miała natomiast ścisły związek $\mathrm{z}$ tym, że delegacja radziecka doprowadziła 10 lutego 1918 r. do zerwania pokojowych pertraktac:ji, które toczyły się w Brześciu nad Bugiem, a w dniu 18 lutego tegoż roku upływal termin trzymiesięcznego układu rozejmowego, podpisanego przez państwa czwórprzymierza (Niemcy, Austro-Węgry, Turcja i Bułgaria) oraz Rosję radziecką. Zaczepne operacje wojsk niemieckich rozpoczęły się 18 lutego, zaś armie austro-węgierskie uczyniły to z dziesięciodniowym opóźnieniem.

W wyniku zimowo-wiosennych działań 1918 r. wojska niemieckie dotarły do środkowych nurtów Dniepru i po Don, a także na Zakaukazie. Armie austro-węgierskie opanowały natomiast tereny po rzekę Boh. Pod kontrolą sprzymierzonych wojsk niemieckich oraz austro-węgierskich znalazły się zatem wszystkie kresowe obszary dawnej Rzeczypospolitej. O sytuacji na tych obszarach w ogromnej mierze decydowało zaś to, że były one widownią wydarzeń rewolucji socjalnej, gwałtownych wystąpień chłopskich, a po części także ukraińskich aspiracji niepodległościowych. Wyrazicielem tych aspiracji stała się Centralna Rada Ukrainska. Te kresowe obszary, ukraińskie i białorusko-litewskie, były jednak zamieszkiwane w znacznym stopniu także przez około cztery, a może nawet pięć milionów ludności polskiego pochodzenia, zaś rozwój wydarzeń powodowal tam zagrożenie stanu polskiego posiadania. Chodzilo $\mathrm{w}$ istocie nie tylko o sprawy majątkowe, ale także o to, że narastało ogólne zagrożenie egzystencji i życia Polaków na tych kresowych obszarach.

Kwestie te znajdują swoje odbicie w dokumentach przeznaczonych do niniejszej publikacji, a znajdujących się w zasobach aktowych Centralnego Państwowego Historycznego Archiwum Ukrainy we Lwowie (dalej: CPHAU we Lwowie). W publikowanych dokumentach są poruszane częściowo także sprawy dotyczące ukraińskich aspiracji niepodległościowych.

Do tekstu publikowanych dokumentów zostały dołączone niezbędne uwagi oraz objaśnienia. W kwadratowych nawiasach są ponadto wprowadzone pełne imiona tych osób, gdy były wymienione tylko ich nazwiska, albo tylko inicjały imion. Zachodziła też niekiedy potrzeba wstawienia pojedynczych słów, jeżeli wydawało się to niezbędne. Takich uzupełnień tekst wymagał na przykład, gdy autorzy dokumentów, mając na myśli Wielkie Księstwo Litewskie, poprzestawali na określeniu: „Wielkie Księstwo". 


\section{Dokument nr 1}

[1915 październik, Lwów]. - Raport komisarza austriackiej policji we Lwowie o nuradzie ukraińskich emigrantów w Stanach Zjednoczonych.

Der in Krakau erschienende „Głos Narodu” reprodiziert in Nummer 267 vom 19 X 1915 folgende Artikel des Lemberger „Wiek Nowy”.

Amerykanischen Blätter zufolge hat am 31 August leitenden Jahres in New York eine Zusammenkunft von Vertretern aller ukrainischen Parteien in den Vereinigten Staaten von Nord Amerika. Stattgef unden.

Zweck dieser Zusammenkunft war die Einberufung eines ukrainischen Kongresses und die Wahl eines Obersten Ukrainischen Nationalkomitees. Über beide Angelegenheiten referierte Doktor Demydczuk. Über Antrag des Władimir Lotecki wurde Einberufung des Kongresses beschlossen.

Auch der Antrag des Miroslaus Siczyński ${ }^{1}$ eine Gescheftsordnung des Kongresses auszuarbeiten und ein vorbereitendes Komitee zu wählen, wurde angenommen. Das Oberste Ukrainische Komitee wird die Aufgabe haben, die in den Vereinigten Staaten von Nord Amerika lebende Ausländer iiber die Ukrainische Frage zu informieren.

Der Kongress wird späterstens in der zweiten Helfte Oktober leitendes Jahres in New York stattfinden.

Dem vorbereitenden Komitee gehören: dr W. Seminowicz, Obmann, M. Siczyński und O. Revwiuk, Referenten, S. Jodłowski und P. Zadoreckij, Schatzmeister.

Podpisal [Reinlender]

Centralne Państwowe Historyczne Archiwum Ukrainy we Lwowie (dalej: CPHAU we Lwowie), fond 146 Namiestnictwo, opis 4, sprawa 44, s. 5.

1 Przy nazwisku wymienionego w tekście uwaga: „Mörder des Staathalters Grafen Andreas Potocki". 


\section{Dokument nr 2}

1915 listopad 21, Lwów. - Raport komisarza policji austriackiej o losach Miroslawa Siczyńskiego w Ameryce.

Prezydium CK Dyrekcji Policji.

Wykonując polecenie z 1 XI 1915 (L. 31819/pr) donoszę w sprawie ruchu między Rusinami w Ameryce Północnej, co następuje.

Tutejsza prasa („Diło” i „Ukraińskie Słowo”), a także tygodnik polityczny dla ludu „Swoboda” poświęcają wiele uwagi ruchowi politycznemu wśród Rusinów Ameryki Północnej, tudzież osobie Mirosława Siczyńskiego dając do zrozumienia, że jest powołany do odegrania wybitnej roli wśród Rusinów amerykańskich. „Swoboda” nr 32 z 21 października 1915 donosi, że Siczyński przybył do Ameryki w końcu 1914 r. ze Szwecji, gdzie przebywał w latach 1913 i 1914 ucząc się szwedzkiego na tamtejszym uniwersytecie i dla nawiązania stosunków z wybitnymi uczonymi szwedzkimi oraz politykami. Pobyt w Stanach Zjednoczonych wykorzystał do napisania broszur w języku angielskim, nakładem Ukraińskiej Rady Narodowej. Mają na celu poinformować społeczeństwo amerykańskie w sprawie ukraińskiej.

Kontaktuje się z Ukraińskim Narodnym Sojuzem i z Ruskim Narodnym Sojuzem w Skrenton.

Po zaznajomieniu się ze stosunkami amerykańskimi, po raz pierwszy publicznie wystąpił na ukraińskim zgromadzeniu w Nowym Jorku 31 sierpnia 1915 i został wybrany jednogłośnie sekretarzem przedsejmowego komitetu w Ameryce.

Stara się o pobyt w Stanach Zjednoczonych. Poczynił kroki do przeprowadzenia przeciw sobie procesu w celu wykazania, że popełnił morderstwo z „pobudek politycznych”. Ustawodawstwo Stanów Zjednoczonych czyni różnicę między zbrodniarzami politycznymi a pospolitymi. W celu jego obrony zawiązal się Komitet Obrony: Dmytro Kapituła - przewodniczący, Iwan Artymowicz - zastępca, Michał Uhorczuk i Jakub Kornet - sekretarze, Andrzej Sawko - kasjer. Obrony mieli się podjąć znakomici adwokaci Nowego Jorku Szymon Polak i Dżilbert Row. Pierwsze przesłuchanie odbyło się 27 września 1915 w Urzędzie Emigracyjnym na Elis Island. Siczyński złożył dokumenty na swą obronę. Do rozprawy pozostaje na wolnej stopie.

Reinlender

CPHAU we Lwowie, fond 146 Namiestnictwo, opis 4, sprawa 44, s. 7. 


\section{Dokument nr 3}

1915 [grudzień, Biala]. - Poufna informacja policyjna o zjeździe obywatelskim Królestwa Polskiego w Piotrkowie Trybunalskim².

W dniach 14 i 15 listopada bieżącego roku bawil w Piotrkowie prezes Naczelnego Komitetu Narodowego [NKN] profesor Władysław Jaworski dla lustracji Departamentu Wojskowego (DW) NNN. W towarzystwie szefa DW podpułkownika Władysława Sikorskiego zwiedzał prezes wszystkie urządzenia i biura DW i przyjrzawszy się pracy wszystkich oddziałów DW, tak wojskowych, jak cywilnych, wyraził najwyższe uznanie szefowi DW za energiczne prowadzenie rozległych prac organizacyjnych.

Na wieść o przyjeździe prezesa Jaworskiego zjechało się do Piotrkowa wielu wybitnych działaczy politycznych Królestwa Polskiego od Płocka po Lublin, tak $\mathrm{z}$ okupacji niemieckiej, jak $\mathrm{z}$ austriackiej dla poinformowania się o pracach NKN i nawiązania bliższych stosunków z przedstawicielstwem polskim zaboru austriackiego. W zaimprowizowanym zjeździe wzięło udział z górą 60 osób reprezentujących różne sfery i zawody, ziemiaństwo, przemysł, kler, instytucje i warstwy ludowe. Blisko połowa uczestników pochodziła z Warszawy. Liczniejsze delegacje przysłało Lubelskie, Łódź, Kujawy i tak dalej.

Obrady miały przebieg niezwykle poważny i wyczerpujący. Głos zabierali przywódcy grup politycznych, wybitni przedstawiciele społeczeństwa w instytucjach samorządu, kierownicy różnych dziedzin współczesnego życia kulturalnego i Gospodarczego Królestwa Polskiego. Obrady wykazały pocieszającą zgodność opinii i żywą dążność do ujednostajnienia ogólnonarodowej akcji politycznej Królestwa Polskiego i Galic.ji. Wyrazy uznania dla pracy NKN mieli mówcy wszystkich obozów politycznych, środka, prawicy i lewicy. Obrady zakończyły się jednomyślnym przyjęciem następującej uchwały.

„Zebrani w Piotrkowie dnia 14 listopada 1915 obywatele Królestwa Polskiego stwierdzają niezachwianie swe dążenie do rozwinięcia w najszerszych kołach społeczeństwa polskiego akcji czynnej dla wyzyskania koniunktur międzynarodowych w celu zdobycia państwa polskiego w wyniku toczącej się wojny.

2 Por. dokument $\mathrm{nr} 5$. 
Za pierwszy i konieczny wyraz tej akcji zebranie uważa Legiony Polskie walczące przeciw Rosji. Solidaryzując się z ideą legionów i jej konsekwencjami zebranie uznaje za konieczne, moralne i naturalne poparcie Legionów Polskich, wzmocnienie ich sił liczebnych przez czynny w nich udział Królestwa Polskiego i uzyskanie dla nich jak najszerszej podstawy w opinii ogółu kraju.

Wszelkie wysiłki zmierzające do skupienia społeczeństwa polskiego około zdobycia państwowości polskiej uczestnicy zebrania rozwinąć pragną $\mathrm{w}$ najściślejszym porozumieniu $\mathrm{z}$ NKN, którego pracę uważają za bezpośredni wyraz polskiej polityki państwowej. Nie przesądzając form organizacyjnych, w jakie ujęta będzie akcja polityczna ogółu polskiego w Królestwie zebranie wyraża przekonanie, iż obowiązkiem poszczególnych jednostek i stronnictw dążących realnie do zdobycia państwa polskiego jest $\mathrm{w}$ dobie obecnej możliwie daleko idące zatarcie różnic partyjnych i zespolenie całej ich działalności w pracy konkretnej i we wszystkich dziedzinach, które doba dzisiejsza na widownię polityki polskiej wysuwa"

Uchwałę powyższą zatwierdzili ponadto uczestnicy obrad swymi podpisami. Dodatkowo przyjęty został jednogłośnie następujący wniosek.

„W myśl zasadniczego wniosku zebrani uważają za konieczne popieranie w całym byłym zaborze rosyjskim werbunku do Legionów Polskich, prowadzonego przez Departament Wojskowy NKN".

CPHAU we Lwowie, fond 146 Namiestnictwo, opis 4, sprawa 5147, s. 12-13.

\section{Dokument nr 4}

1915 jesień, [Biala]. -- Raport dla austriackiego ministra spraw wewnętrznych o polskim ruchu narodowym w Ameryce.

Haltung der Polen in den Vereinigten Staaten

Von Nordamerika seit Ausbruch des Krieges.

Wird dem Herrn k.k.Staathalter in Galizien nach Einsichtnahme rückgemittelt.

Für den k.k. Minister des Innern. 


\section{Załącznik.}

Informacja o ruchu narodowym polskim w Ameryce ${ }^{3}$.

Rozwój ruchu niepodległościowego w Galicji, a łącznie z nim w Królestwie Polskim musial wywrzeć i rzeczywiście wywarł wpływ na prawie czteromilionową masę wychodźstwa polskiego w Ameryce. Wyrazem, niejako echem tego ruchu był wielki zjazd narodowy, jaki się odbył w roku 1912 w mieście Pittsburghu z udziałem wszystkich zrzeszeń i organizacji polskich w Ameryce. Jednogłośnie i z wielkim entuzjazmem uchwalono walkę z Rosją jako nie tylko wrogiem Polski, ale żandarmem całej Europy i postanowiono utworzyć organizację polityczną, nową, mającą za zadanie popieranie Polskiego Skarbu Wojskowego, szerzenie wśród wychodźstwa propagowanej walki czynnej przeciw Rosji na wypadek wojny i poddano tę nową organizacje pod dyrektywę polityczną Komisji Tymczasowej, przemienionej następnie na Komisję Skonfederowanych Stronnictw Niepodległościowych.

W ten sposób powstał Komitet Obrony Narodowej w Północnej Ameryce jako pierwsza czysto polska organizacja na wychodźstwie, a do zarządu jej weszli przedstawiciele największych polskich organizacji, a więc przede wszystkim Związku Narodowego Polskiego, dalej klerykalnego Zjednoczenia Rzymsko Katolickiego, Związku Sokołów Polskich i tak dalej. Żywioły w poważnej części nie mające żadnej łączności z krajem rodzinnym, zamerykanizowane, spostrzegły wkrótce, że wszelka poprawa doli narodu polskiego zagraża tak prywatnym interesom, które zarówno w karierze polityczno-amerykańskiej i w zyskach płynących z ich zajęć, opierają się, w znacznej mierze na masie wychodźstwa. Pierwszy zorientował się w tym kierunku kler polsko-amerykański, który przewidywał pomniejszenie się parafii na wypadek zmiany losu na lepsze w kraju. Widział także w tym zrzeszeniu się ludzi wielkich stronnictw zagrożenie jego władzy nad duszami polskimi, którą do tej pory prawie niepodzielnie trzymał w swych rękach. Starał się tedy nowopowstałą organizacją zawładnąć, a gdy mu się to nie udało, pierwszy wyłamał się spod solidarności narodowej, wystąpił z KON i pociągnął za sobą wszystkie organizacje klerykalne, $\mathbf{z}$ których następnie wytworzył nowe zrzeszenie o charakterze politycznym, tak zwaną Radę Narodową. Za

3 Informacja razi tendencyjnym, partyjnym, nadmiernie lewicowym ujęciem poruszanych spraw. 
przykładem kleru poszli również menerzy Związku Narodowego Polskiego, oddani ciałem i duszą Narodowej Demokracji i według jej wskazówek kierujący polityką największego polskiego Towarzystwa Asekuracyjnego, które prawem kaduka przywłaszczyło sobie prawo reprezentac.ji narodu polskiego na zewnątrz. Ta ostatnia secesja miała pociągnąć za sobą i pociągnąć musiała usuwanie się z Komitetu Obrony Narodowej i Związku Sokołów Polskich w Ameryce, których prezes doktor [Teofil] Starzyński podczas swego pobytu w Europie szukał orientacji w tych samych źródłach (Narodowej Demokracji), z których zaczerpnęli jej rzekomi dygnitarze Związku Narodowego Polskiego [Antoni] Karabasz i [Adolf] Rakoczy, wysłani przed wojną do Galicji.

W ten sposób, gdy wybuchła wojna Komitet Obrony Narodowej właściwie zagrożony był $\mathrm{w}$ podstawach swego bytu, a jeżeli mimo to poddawszy się po stworzeniu Naczelnego Komitetu Narodowego w kraju, jego władzy, przetrwał te ciężkie chwile, jak inwazja rosyjska w Galicji wschodniej, zajęcie Lwowa, zagrożenie Krakowa, to należy to przypisać nie tylko tej okoliczności, że się koło niego skupiło wszystko, co w Ameryce spośród wychodźstwa polskiego jest czystym, szlachetnym i wykształconym, ale przede wszystkim sztandarowi, który KON w Ameryce podniósł, sztandarowi legionów i imieniu Piłsudskiego. Przeciwnicy nie ustawali w swoich atakach zarówno na samą organizację, jak i poszczególnych jej członków starając się zohydzić ich ideową pracę zarzutem sprzedajności rządowi austriackiemu i niemieckiemu oraz materialnym bojkotem poszczególnych jednostek, a chcąc swej działalności nadać jak najsilniejszą podstawę stworzyli nowe zrzeszenie, które pod nazwą Centralny Narodowy Komitet Polski połączył Radę Narodową, Wydział Niepodległościowy, Związek Narodowy Polski, Związek Sokołów Polskich, Związek Polek i szereg drobniejszych organizacji idących luzem. Ponieważ na czele prawie wszystkich polskich organizacji stoją te jednostki z emigracji polskiej, które od dawna w Ameryce osiadły, doszły nie tylko do pewnej, stosunkowo znacznej zamożności, ale także zyskały sobie na tej podstawie pewne stanowisko w amerykańskim życiu politycznym, a więc jednostki pochodzące z najdawniejszej emigracji polskiej, jaka powstała pod zaborem pruskim w porze tak zwanego Kulturkampfu i w następstwie późniejszych ustaw wyjątkowych przeciw Polakom, przeto nie można się dziwić, ze dla ludzi tych myśl połączenia losu Polski z losami państw centralnych w tej wojnie, a przede wszystkim Niemiec, było wprost niepojętą, a w odczuciu krzywd poniesionych mogło się wydawać wprost zdradą sprawy narodowej. 
W tym leży główna przyczyna prądu wszechpolskiego ${ }^{4}$ wśród Polaków w Ameryce, któremu nie na rękę szła jeszcze ogólna tendencja polityki amerykańskiej, upatrując największą korzyść z tej wojny w zgnębieniu Niemiec przez Rosję i uwolnieniu w ten sposób rynków rosyjskich od wpływu przemysłu, handlu i kapitału niemieckiego, który miał zastąpić kapitał amerykański, nie tylko $\mathrm{z}$ wielkim zyskiem materialnym dla siebie, ale i z misją polityczną przez wpływy Rosji trzymania w szachu Japonii, najgroźniejszego przeciwnika w dobie obecnej Stanów Zjednoczonych Ameryki Północnej.

Jako przeciwwaga tym tak potężnym czynnikom opinii politycznej polskiej w Ameryce zaważyła na szali stosunków polskich krew bohatersko przez legiony przelana. Jej należy zawdzięczać, że kierunek polityczny Komitetu Obrony Narodowej idący po linii wytyczonej przez NKN mimo tych wszystkich przeciwności nie tylko nie traci na znaczeniu, lecz wychował sobie prawo obywatelstwa coraz to w nowych masach wychodźstwa polskiego, w czym znaczna zasługa przypada także delegatom NKN Antoniemu Hausnerowi i doktorowi [Feliksowi] Młynarskiemu, którzy szeregiem odbytych zebrań poruszyli nie tylko serca wychodźców, ale potrafili wykrzesać z nich szczery entuzjazm, którego wymową były hojne datki i ofiary w kosztownościach na cele legionów i NKN. Dzisiaj Komitet Obrony Narodowej w Ameryce posiada 100 komitetów lokalnych we wszystkich stanach Ameryki, położonych od Atlantyku po Pacyfik, w których grupuje się to wszystko, co $\mathrm{z}$ wychodźstwa polskiego pozostało $\mathrm{w}$ ścisłej łączności $\mathrm{z}$ krajem rodzimym pod hasłem: „Walki zbrojnej z Rosją o niepodległość kraju”, pod hasłem legionów i polityki NKN, w zwartej organizacji liczącej dzisiaj około 100000 członków i sympatyków 5 .

Walka polityczna, prowadzona przez organizacje, pociągnęła za sobą w naturalnym następstwie i rozdział pism polsko-amerykańskich na dwa zasadnicze z sobą sprzeczne obozy. Jedne stanęły na linii wytyczonej uchwałą Koła Polskiego z 16 sierpnia 1914, inne zaś uznały ten krok nie tylko jako objaw zapatrywań politycznych zaboru austriackiego, lub też wprost uznały tego rodzaju politykę za zgubną dla kraju znajdując nadzieje lepszego bytu

4 Autorzy mają na myśli ruch polityczny związany z Ligą Narodową, która funkcjonowała poufnie na obszarze wszystkich dzielnic ziem polskich pod ogólnym kierunkiem Romana Dmowskiego.

5 Jawna przesada autorów elaboratu. Stwierdzenia te nie znajdują potwierdzenia w ustaleniach historiografii polskiej. 
Polski jedynie w realizowaniu obietnic poczynionych w odezwie wielkiego księcia Mikołaja Mokołajewicza ${ }^{6}$.

$\mathrm{Na}$ tym programie zjednoczenia ziem polskich pod panowaniem Rosji oparły swą działalność polityczną w pierwszym rzędzie organy urzędowe Związku Narodowego Polskiego: „Dziennik Związkowy”, tygodnik „Zgoda”, „Dziennik Narodowy” własność znanego w świecie amerykańsko-politycznym, bankiera i adwokata J[ana] Smulskiego, obdarzonego orderem austriackim (wszystkie wychodzą w Chicago); „Rekord Codzienny” w Detroit, dziennik i tygodnik „Ameryka Echo” w Toledo, mające największą ilość prenumeratorów w Stanach Zjednoczonych, „Wielkopolanin” w Pittsburghu, „Sokół Polski” w Pittsburghu, organ Związku Sokołów Polskich w Ameryce, „Głos Polek”, organ Związku Polek w Chicago, „Kurier Polski” w Molwaukee, własność J. Kruszki z Poznańskiego i pomniejsze o niestałyın bycie.

Na programie NKN opierają swą działalność przede wszystkim organ urzędowy KON tygodnik „Wici” oraz wydawany w języku angielskim dwutygodnik „Polish Cause” (Chicago), urzędowe organy partii socjalistycznej, „Dziennik Ludowy” w Chicago i wychodzący dwa razy w tygodniu w Nowym Jorku „Robotnik Polski”, „Dziennik Polski” w Detroit. „Telegram Codzienny” w Nowym Jorku, organ młodzieży polskiej „Pobudka” w Bostonie, tygodnik „Hasło” w Pittsburghu i „Narodowiec” w Clewlend oraz liczne organy pomniejsze prasy prowincjonalnej.

Pomiędzy tymi dwoma obozami, jako wyraz polityki czekania i nie opowiadania się Polski za żadną ze stron $\mathrm{w}$ tej wojnie stoi przede wszystkim organ stronnictwa klerykalnego, wydawany przez Ojców Zmartwychwstańców w Chicago „Dziennik Chicagowski” oraz organ kleru świeckiego „Nowiny Polskie" w Miwaukee, te ostatnie już jednak więcej $\mathrm{z}$ tendencją ku polityce rusofilskiej, dalej popularny tygodnik „Gwiazda Polarna” orientacji neutralnej.

„Dziennik dla Wszystkich” w Buffalo stoi wprawdzie zdecydowanie po stronie legionów i walki zbrojnej z Rosją, nie posiada jednak całkiem zdeklarowanej bazy politycznej ze względu na częste ustępstwa czynione w celach nie zniechęcania do siebie stronnictw.

Rada Narodowa wydaje dwutygodnik w języku angielskim „Free - Poland" w Chicago, który nie zdradzając żadnych tendencji moskalofilskich stoi na stanowisku narodowo-prawicowym linii politycznej NKN.

6 Bezpodstawny zarzut nie potwierdzony rozwojem późniejszych wydarzeń. 
Ogólnie zauważyć: należy, że stanowisko Polaków w Ameryce jest bardzo trudne, wobec orientacji, której hołdują inne narodowości słowiańskie w Ameryce. Urządzane są przez nią wiece demonstracyjne, na których Czesi, Kroaci ${ }^{7}$ i inni Słowianie pieją hymny na cześć Rosji, wypowiadają się po stronie Rosji i Ententy i piętnują Polaków jako zdrajców sprawy słowiańskiej, nieraz, jak to miało miejsce na wiecu demonstracyjnym w Chicago, nawet przy dźwiękach hymnu rosyjskiego.

Brak podpisu autora, czy też autorów raportu.

CPHAU we Lwowie, fond 146 Namiestnictwo, opis 4, sprawa 5147, s. 27-30.

\section{Dokument nr 5}

1915 grudzień 7, Biala. - Raport funkcjonariusza austriackiej policji dla c.k. Prezydium w Krakowie o przebiegu wizyty warszawskich dzialaczy politycznych $w$ Krakowie $i$ o ich naradzie $w$ sprawach reemigracji Polaków $z$ Ameryki.

W dniach 7 i 9 grudnia bawili w Krakowie zaproszeni przez Prezydium NKN przedstawiciele inteligencji warszawskiej należący przeważnie do ugrupowań partyjnych centrowych. Byli to adwokaci Wacław Łypacewicz, Leon Supiński ze Zjednoczenia Postępowego, redaktor „Dziennika Polskiego" Bogdan Straszewicz, właściciel dóbr Jan Rogowicz z grupy Pracy Narodowej, dyrektor banku i komisarz miejskiej milicji Tadeusz Szemplinski, właściciel biura techniczno-przemysłowego doktor Ludwik Zieliński ze Zjednoczenia Narodowego, adwokat Franciszek Paschalski, adwokat Stanisław Patek, adwokat Tadeusz Tomaszewski z Grupy Narodowych Radykałów, inżynier Stanisław Śliwiński, inżynier Medard Downarowicz, dyrektor cukrowni Jan Godlewski ze Związku Patriotów, wreszcie adwokat Leon Papieski, bezpartyjny.

Przyjechali do Krakowa dla naradzenia się nad sprawą reemigracji z Ameryki. Zebranie w sprawie reemigracji zapowiedziane i ogłoszone w prasie krakowskiej odbyło się 7 grudnia w sali magistratu. Sprawę o reemigracji referował doktor Bochenek z Krakowa, członek Komitetu Obrony Narodowej

7 Chodzi o Chorwatów. 
w Ameryce, będącego w stałym porozumieniu z NKN, niedawno przybyły z Ameryki.

W referacie doktor Bochenek podniósł fakt, że po wojnie można się spodziewać znacznego napływu Polaków z Ameryki, którzy zaopatrzeni w pewne zasoby pieniężne mogliby w kraju albo osiąść na ziemi, albo też zająć się po miastach handlem i przemysłem. Zachodzi jednak niebezpieczeństwo, że ta naturalna i normalna dążność do kraju emigrantów mogłaby być wykorzystana przez spekulantów, którzy by z jednej strony wyzyskali tę emigrację, a z drugiej skierowaliby ją na tory dla interesów kraju niepożądane. Chodziłoby przeto o dokładne zbadanie tej sprawy i o ewentualne utworzenie instytucji, która by się zajęła regulacją reemigracji.

Dyskusja zebrania była prowadzona w zakresie powyższych przesłanek. Zebranie jednomyślnie przyszło do przekonania, że na razie należy powstrzymywać tę reemigrację, dopóki wojna nie zostanie ukończoną i dopóki nie wyjaśni się sytuacja w kraju i że należy poczynić przygotowania, aby z chwilą, kiedy reemigracja stanie się kwestią aktualną, została ona zwrócona na właściwe tory. Postanowiono tedy wydać kwestionariusz, który został ułożony tak, aby w rezultacie można było otrzymać dokładny obraz charakteru ruchu reemigracyjnego. Ponadto przyjęto jednogłośnie odezwę podpisaną przez wszystkich obecnych, która charakteryzuje opinie konferencji.

Korzystając z przyjazdu NKN udzielił wymienionym przedstawicielom informacji o sytuacji i dokładał starań, by wpływać na nich w duchu swej polityki. W tym celu zostali oni zaproszeni na plenarne zebranie NKN, po czym odbył się na ich cześć bankiet. Na zebraniach tych zaznajomiono gości z poszczególnymi instytucjami i pracami NKN, oni zaś wzajemnie informowali członków NKN o sytuacji panującej w Królestwie, przede wszystkim zaś pod okupacją niemiecką. Ich opinia streszcza się w następujących głównych punktach.

1. Zachowanie się władz niemieckich tak pod względem politycznym, jak i ekonomicznym wytwarza nastrój bardzo nieprzychylny dla Niemiec. Szykany, cenzorska działalność [Georga] Cleinowa, który postępuje prowokacyjnie, zakazuje wszelkich wzmianek o legionach, tępi wszelkie wypowiedzi prasy w kierunku polityki NKN, natomiast foruje i popiera wszystko, co mogłoby szkodzić Austrii; bezwzględna polityka władz niemieckich, wysysająca niepospolicie kraj, niszcząca przemysł; prześladowanie objawów samodzielności społeczeństwa, aresztowania w kołach żywiołów skrajnie antyrosyjskich - wszystko to usposabia ogół ludności wrogo względem Niemiec.

2. Moskalofilstwo nie istnieje. Królestwo i Warszawa już nie wierzy w powrót Moskali, ale obawia się tendencji aneksyjnych ze strony Niemiec, gdyż 
władze niemieckie, działając w Królestwie wbrew temu, co powiedział kanclerz w swojej mowie, zachowują się tak. jakby dążyły do podziału Królestwa Polskiego, co miejscowa ludność uważałaby za taką samą klęskę, jak oddanie Królestwa z powrotem Rosji.

3. Na tle takiego stosunku do Niemiec sprawa legionów w opinii publicznej przedstawia się opłakanie. Gorące sympatie dla legionów, szerzące się coraz bardziej nie mogą być zrealizowane w postaci zwiększonego werbunku, gdyż szeroki ogół tych zwłaszcza żywiołów, które mogą dać rekruta, nie uważa za stosowne popierać wydatnie siłę zbrojną państw centralnych, dopóki te nie wypowiedziały się zupełnie stanowczo o przyszłym losie Polski i o niepodległości Królestwa. Propaganda legionowa jest zwłaszcza utrudniona wobec nieubłaganego stanowiska cenzury niemieckiej w Warszawie.

4. Z tym wszystkim wiąże się sprawa reprezentacji Królestwa Polskiego, sprawa Rady Narodowej ${ }^{8}$, która dotychczas jeszcze nie została utworzona, jakkolwiek opinia publiczna Warszawy i całego Królestwa uważa jej utworzenie za konieczne. Głównymi przeszkodami utworzenia się Rady Narodowej są obawy, że będą groziły jej represje ze strony władz niemieckich oraz niemożność na razie skoordynowania się rozbieżnych obozów politycznych Królestwa Polskiego na gruncie dokładnie określonych postulatów.

Przedstawiciele NKN informując gości warszawskich o sytuacji starali się oddziaływać na nich w kierunku uspokajającym. Jaworski wymownie zalecal im, aby niechęć Królestwa wobec Niemiec starali się skierować w łożysko sympatii dla Austrii przez przeciwstawienie pierwszych tej ostatniej. Członkowie NKN tłumaczyli konieczność wytworzenia się reprezentacji Królestwa Polskiego i zalecali organizowanie zjazdów, czy to poszczególnych grup politycznych, czy to rozmaitych korporacji, które by popierały uchwały wyrażające opinie Królestwa Polskiego i jego front antyrosyjski.

Uchwały te wobec chwilowego braku ogólnej reprezentacji Królestwa Polskiego były wyrazem opinii tego ostatniego.

Z porozumień tych odniosło Prezydium NKN ogólne wrażenie, że goście warszawscy, powróciwszy do Warszawy, będą oddziaływali na otaczające ich sfery w duchu polityki NKN.

Działalności NKN dotyczy także informacja poufna o zjeździe obywatelstwa Królestwa Polskiego w Piotrkowie z dnia 14 i 15 listopada $1915^{9}$.

8 Szeroko o tych sprawach pisze Jan Molenda, Pilsudczycy a narodowi demokraci. 1908-1918, Warszawa 1980.

9 Por dokument nr 2. 
Donosząc o tym powołuje się na relację z dnia 12 grudnia 1915, L. 3550/pr. Oraz na reskrypt $\mathrm{z}$ dnia 6 grudnia 1915, L. 37057/pr.

Za c.k. Radcę Dworu i Dyrektora Policji Reinlendera ${ }^{10}$.

CPHAU we Lwowie, fond 146 Namiestnictwo, opis 4, sprawa 5147, s. 14-17.

\section{Dokument nr 6}

1916 styczeń 12, Biala. - Raport policji austriackiej o utworzeniu w Galicji polskiego Komitetu Ochrony Ziemi.

„Kurier Lwowski” nr $1 \mathrm{z}$ dnia 1 stycznia $1916 \mathrm{w}$ artykule pod tytułem "Straż przy ziemi polskiej” omawia akcję w sprawie utrzymania ziemi w rękach polskich.

Wedle powyższego artykułu utworzył się w tym celu pod patronatem księży arcybiskupów Komitet Ochrony Ziemi w następującym składzie: prezes Stanisławowa Wołkowicka, wiceprezesi - K. Smoleńska, J. Steczkowska, skarbnik - Teodozja hrabina Dzieduszycka, sekretarz - Sydonia Musiałówna, [członkowie] - Jeske Choiński (Warszawa), Andrzej książę Lubomirski, A[leksandder] Cieński, St[anisław Lewandowski, Wincenty Witos, hrabia Rzewuski. Adres komitetu: Stanisławowa Wołkowicka, Wiedeí IV Stahrembergstrasse $37 / 7$.

Komitet ten wydal odezwę do społeczeństwa $\mathrm{z}$ wezwaniem do poparcia prac komitetu, a w celu obmyślenia ogólnego planu akcji rozesłał do prawników kwestionariusz z odpowiednimi zapytaniami.

Przy komitecie powstała także sekcja amerykańska, w skład której wchodzą: ksiądz Krechowicz, doktor N[ikodem] Piotrowski (Chicago), W. hrabina Dębicka, E. Mizerowa, K. Chodziński.

Utworzenie sekcji amerykańskiej przy komitecie pozostaje w związku $\mathrm{z}$ akcją w sprawie powrotnej emigracji Polaków amerykańskich, aby w ten sposób poprzeć przypływ do kraju kapitałów i sił roboczych.

Powyższą akcję omawia także „Dziennik Polski” w numerze 27 z 12 stycznia 1916.

10 Brak podpisu, ponieważ publikowany dokument jest kopią. 
Na powyżej przedstawioną akcję pozwalam sobie zwrócić uwagę Prezydium przy dołączeniu cytowanych numerów czasopism z powołaniem się na reskrypt Prezydium c.k. Namiestnictwa z dnia 6 grudnia 1915, L. 37057/pr.

C.k. Radca Stanu i Dyrektor Policji: Reinlender.

CPHAU we Lwowie, fond 146 Namiestnictwo, opis 4, sprawa 5147, s. 24-25.

\section{Dokument nr 7}

[1916], Biala. - Informacja poufna $z$ niestosownymi insynuacjami o dzialalności Ignacego Paderewskiego w Ameryce.

Poprzedzony wieściami o urządzanych przez niego w Paryżu i Londynie dniach polskich $\mathrm{z}$ udziałem ambasadorów rosyjskich oraz wywiadach $\mathrm{w}$ prasie angielskiej. w których zapewnial, że serca 25 milionów Polaków ujętych boskim uczuciem litości narodu rosyjskiego względem polskiego biją w takt odezwy wielkiego księcia [Mikołaja Mokołajewicza], przybył pan I[gnacy ] Paderewski do Ameryki jako wiceprezes Komitetu Vewejskiego celem zaaranżowania szerokiej akcji na rzecz ofiar wojny w Polsce. Akcja jego miała być wyłącznie filantropijna, a angielskie i polskie dzienniki przynosiły całą masę szczegółów o tym wielkim jałmużniku polskin, który złożywszy cały majątek na cele ojczyzny, za pożyczone pieniądze przybywał do Ameryki i tam rozpoczynał swą filantropijną działalność.

Jak wiadomo poprzednio już założony został w Nowym Jorku komitet amerykańsko-polski pod patronatem pani Sembrich-Kochańskiej, która wciągnąwszy do niego Polaków o wybitnym stanowisku i znane osobistości świata amerykańskiego, potrafiła zyskać dla niego uznanie wśród Amerykanów. Pan Paderewski pomimo zapowiedzianej czysto filantropijnej działalności począł się zajmować polityką na gruncie amerykańskim. Nie występując publicznie gromadził koło siebie ludzi zajmujących się sprawami polskimi i wtajemniczał ich $\mathrm{w}$ rzekomo najświeższe wiadomości przywiezione $\mathrm{z}$ kraju, a między innymi o znienawidzeniu, jakie ściągnęli na siebie przewodnicy NKN panowie Jaworski i Daszyński, którzy według wyrażenia pana Paderewskiego nie mogli się ukazać na ulicy bez opieki żandarmów. Poza tym przez osoby sobie oddane wniósł echo waśni politycznych do komitetu pani Sembrich, wskutek których z komitetu tego przestano wysyłać pieniądze do NKN. Mimo tego tryumfu na rzecz reprezentowanego przez 
siebie kierunku pan Paderewski uważał za stosowne założenie drugiego komitetu dla spraw polskich z ludzi powołanych przez siebie, a w ten sposób przekonawszy społeczeństwo amerykańskie dowodnie o niejednolitym poglądzie Polaków na sprawę polską wpłynął ujemnie na wydatność składek płynących zarówno do komitetu pani Sembrich-Kochańskiej, jak i nowego, przez pana Paderewskiego organizowanego, pomimo, że tenże posługiwał się iście amerykańską reklamą rozsyłając odezwy z portretem Paderewskiego i wezwaniem do składania pieniędzy na pomoc narodowi, który wydał Sobieskiego, Kościuszkę, Sienkiewicza i Paderewskiego.

W politycznej swej działalności wygłosił on na wielkim obchodzie polskim przemowę (wyjątek dołączamy) zaznaczającą jego apolityczną orientację, ponieważ chwalił zarówno Legiony Polskie, jak i legiony zorganizowane przez [Witolda] Gorczyńskiego, a przemówieniu temu towarzyszył charakterystyczny incydent, gdy jałmużnik polski zirytowany głośnym zachowaniem się zamerykanizowanej młodzieży polskiej krzyknął donośnie: „cicho bydło". Pomimo tego postępowanie jego zyskało powszechny aplauz, a nawet z jałmużnika został przez redaktora „Dziennika Związkowego”, ongiś poczmistrza na galicyjskiej poczcie w Przeciszowie, który po zdefraudowaniu przekazu pocztowego na sumę 720 koron zbiegł do Ameryki, podniesiony do godności hetmana polskiego.

Hetmaństwo to jednak nie oddziaływało widać na społeczeństwo amerykańskie, ponieważ składki napływały niesłychanie powoli i dały rezultat jako sumę śmiesznie małą w porównaniu do 60 milionów dolarów zebranych w Ameryce przez Belgię, a nawet 6-ciu posłanych do Serbii. Cała jednak prasa moskalofilska zyskała oparcie w prestiżu nazwiska może najbardziej znanego z polskich w Ameryce. A gdy, mimo wysiłków skierowanych ku uniemożliwieniu pracy Komitetu Obrony Narodowej, podległego Naczelnemu Komitetowi Narodowemu, tenże stale swoją działalność rozwijal, postanowiono wyzyskać informacje udzielone poufnie przez Paderewskiego o sprawach krajowych do zanknięcia działalności biura Komitetu Obrony Narodowej przez denuncjację przed władzami amerykańskimi, że wysłańcy NKN panowie A[rtur] Hausner i doktor [Feliks] Młynarski za pruskie i austriackie pieniądze zajmują się wśród Polaków i innych Słowian amerykańskich agitacją na rzecz Austrii i Niemiec werbując ochotników do austriackiego Landsturmu.

Sprawę tę poruszono w chwili, gdy opinia amerykańska poruszoną była do żywego aferą ambasadora austriackiego pana Dumby, który nieopatrznie powierzył nader ważne listy, zwierające wskazówki dla rządu austriackiego w sprawie ewentualnych strajków w amerykańskich fabrykach broni 
i amunicji dziennikarzowi panu Arskibaldowi, cała prasa anglo-rusofilska wykorzystała ten ewenement na niekorzyść polityki mocarstw centralnych, których stanowisko i tak w Ameryce nie jest zbyt silne wobec ciągłych zatargów z Niemcami o sprawę wolnej żeglugi. W piśmie angielskim „Free Presse", wychodzącym w Detroit, pojawił się cały szereg artykułów, w których oskarżając delegatów NKN o działalność naruszającą neutralność Stanów Zjednoczonych żądano wytoczenia śledztwa przez władze federalne zarówno samym delegatom, jak i Komitetowi Obrony Narodowej, w porozumieniu z którym delegaci działali. Gdy KON zażądał sprostowania podanych wiadomości uczyniono to niechętnie powołując się na tę okoliczność, że denuncjacje owe pochodziły ze źródła polskiego, wymieniono jako głównego donosiciela znanego Naczelnemu Komitetowi Narodowemu redaktora z Ameryki pana Wasikowskiego oraz szereg kryminalnych figur, a gdy zwrócono uwagę na przeszłość tych donosicieli w nowojorskim „Timesie”, przedrukowującym stale rewelacje „Free Presse”, pojawił się dnia 16 września artykuł, w którym oświadczono, że informacje te pochodzą z tego samego źródła, jak pan Paderewski, wiceprezes Komitetu Vewejskiego, który udzielał ich w listach prywatnych swoim amerykańskim znajomym.

Ponieważ delegat pan Hausner już był wyjechał z Ameryki, przeto pozostały drugi delegat doktor Młynarski zwrócił się do Paderewskiego z prośbą o zdementowanie imputowanych mu informacji, czego jednak pan Paderewski do 6 października nie uczynił. Wprawdzie zarzuty podniesione przeciw delegatom NKN nie przyniosły może materialnej szkody sprawie niepodległości polskiej, bo na przykład telegram wysłany przez delegata Młynarskiego do prezydenta Wilsona ze szczegółowymi informacjami o zadaniach i stanowisku NKN oraz legionów uzyskał w Białym Domu przychylne przyjęcie, to jednak takie świadome mieszanie sprawy polskiej $\mathrm{z}$ działalnością mocarstw centralnych nie może się przyczynić do uzyskania sympatii dla pierwszej, zwłaszcza, że zarówno interes, jak snobizm amerykański każą stać Amerykanom po stronie Rosji i Anglii. Że postawienie kwestii polskiej przez pana Paderewskiego w ten sposób, jak on to uczynil, nie zyskało w społeczeństwie amerykańskim uznania, tego najlepszym dowodem jest przerzucenie się Paderewskiego do urządzania koncertów na rzecz Polski, na co początkowo, jak twierdził złamany przejściowo duch nie pozwalał.

Obecnie zapowiedziany jest cały szereg koncertów Paderewskiego w całych Stanach Zjednoczonych, z których jednak tylko trzy przeznaczone są na Polskę, ale i $z$ tych zapewne dochód będzie wyższy niż dotychczasowe składki, o ile można sądzić po pewnym, urządzonym w połowie września w San Francisco. 
Załącznik

Wyjątek z mowy Ignacego Paderewskiego w Ameryce.

„Obietnica ta (oszukanicza odezwa wielkiego księcia Mikołaja Mikołajewicza zapowiadająca zjednoczenie Polski z Rosją w języku i wierze ${ }^{11}$ ) trafiła wprost do serca każdego z 25 milionów mych rodaków... usunęła wszelkie powątpiewanie, które mogło istnié: w umysłach Polaków spod pruskiego i austriackiego zaboru względem celu, o który walczą sprzymierzeni, a którym jest zasada narodowości, za którą cierpieliśmy przez wiele stuleci. Jedna rzecz zaś wznosi się ponad wszystko, o której uczucie zmusza mnie wspoinnieć, a mianowicie wspaniałe panowanie nad sobą i zachowanie się Rosjan w Polsce. Jest ono cudownym i właściwie względem nas zdobywa dla nich serca wszystkich Polaków".

CPHAU we Lwowie, fond 146 Namiestnictwo, opis 4, sprawa 5147, s. 32-35.

\section{Dokument nr 8}

1917 listopad 11, Bialystok. - Wystqpienie Centrali Obwodu Bialostockiego do parlamentarnego Kola Polskiego w Wiedniu o poparcie zabiegów majqcych na celu przylqczenie Bialostocczyzny do Królestwa Polskiego.

Do Prześwietnego Koła Polskiego w Wiedniu.

Niebawem po powstaniu nie istniejącej dzisiaj [Tymczasowej] Rady Stanu Królestwa Polskiego miasto Białystok z prowincją przesłały były tejże jednocześnie $\mathrm{z}$ wyrazem holdu, jako reprezentantce władzy naczelnej odradzającego się Królestwa Polskiego, adres opatrzony licznymi podpisami o czynieniu starań o przyłączenie Obwodu Białostockiego do Królestwa Polskiego.

Obecnie Centrala Obwodu Białostockiego, powołana do czuwania nad potrzebami ekonomiczno-społecznymi i kulturalno-oświatowymi trzech powiatów - białostockiego, sokólskiego i bielskiego - zanosi do Prześwietnego Koła Polskiego w Wiedniu tę samą prośbę o przedsięwzięcie na arenie politycznej kroków zmierzających do możliwie rychłego przyłączenia grani-

11 Uwaga autora policyjnego raportu. 
czących pomiędzy Królestwem a Litwą trzech powiatów - białostockiego, sokólskiego oraz bielskiego i stanowiących tak zwany Obwód Białostocki.

Pod rządami Ober-Ostu (Oberbefehlshaber Ost) ${ }^{12}$ kraj ten cierpi srogi ucisk ekonomiczny i kulturalny. Ludność pamięta o tym, że stanowiła część składową Korony i pragnie z Królestwem polskim jak najprędzej się połączyć.

\section{Wiceprezes Centrali ksiądz P. Piekarski \\ Prefekt Gimnazjum Realnego}

Sekretarz Józef Zmitrowicz

Dyrektor Gimnazjum Realnego w Białymstoku

CPHAU we Lwowie, fond 717, opis 1, sprawa 15, s. 96.

\section{Dokument nr 9}

[1918 marzec, Kowel, albo Wlodzimierz Wolynski]. - Memorial skierowany do parlamentarnego Kola Polskiego w Wiedniu przez przedstawicieli ludności polskiej zachodnich obszarów Wolynia z prośbq o interwencję $w$ sprawie przylqczenia tych terenów do państwa polskiego.

Zachodnie dwa powiaty Wołynia (kowelski, włodzimierski), znajdujące się w okupacji armii austro-węgierskiej, przedstawiają obszar mniej więcej 12000 kilometrów kwadratowych i dawniej, za czasów Rzeczypospolitej, w większej części wchodziły w skład tak zwanej Ziemi Chełmskiej, w mniejszości zaś stanowily zachodni skrawek województwa wołyńskiego.

Jako pogranicze między państwem polskim za Piastów i dzierżawami wciąż zmniejszającymi się udzielnych książąt ruskich i litewskich - ziemie te w przeciągu X-XIV wieku kolejno wchodzily to w skład państwa polskiego, to w skład rozmaitych księstw ruskich i litewskich. Od 1366 r. ostatecznie przyłączone do Polski dzieliły z nią wszystkie losu koleje do ostatniej chwili egzystencji Rzeczypospolitej; na mocy ostatniego traktatu rozbiorowego Polski w roku 1795 ziemie te przeszły w posiadanie Rosji, skąd uwolniły je

12 Ober - Ost (Oberbefehlshaber Ost), to Naczelny Dowódca Wojsk Niemieckich na Wschodzie. Miał do swojej dyspozycji tak zwany Cywilny Zarząd, odpowiedzialny za administrację obszarów okupowanych przez wojska niemieckie. 
dopiero zwycięskie armie państw sprzymierzonych w roku 1915, w związku z. którymi walczyły od początku Legiony Polskie, które właśnie na terenie wołyńskim, nad Styrem i Stochodem dokonały najświetniejszych swych czynów wojennych.

Czując nierozerwalny swój związek z Polską, swą Macierzą, ziemie te najdobitniej dokumentowały swój protest przeciw rozbiorom Polski i zawsze walczyły o całość i niepodległość Ojczyzny i w ruchach zbrojnych zwróconych przeciw Rosji poczynając od powstania Kościuszki 1794, następnie w latach 1831 i 1863 i wysyłając swych synów do Legionów Polskich w obecnej wojnie.

Nie bacząc na najsroższe represje rządu rosyjskiego przeciw żywiołowi polskiemu w tym kraju, szczególnie po ostatnim powstaniu 1863 r., jak to: masowe konfiskaty majątków, zakaz kupowania ziemi przez Polaków i nawet lokowania kapitałów polskich na hipotekach ziemskich, zupełne zgnębienie szkolnictwa, zakaz zakładania wszelkich stowarzyszeí o charakterze społecznym, a nawet w wielu wypadkach i ekonomicznym - charakter ogólny tego kraju i dzisiaj musi być nazwany polskim i li tylko taki.

$\mathrm{Na}$ to składa się wiele czynników.

W pierwszym rzędzie w skład polskiej ludności wchodzą wszystkie warstwy społeczne w przeciwieństwie do innych grup narodowościowych, jak Rusini i Żydzi, z których pierwsi składają się jedynie z włościan i drobnych rzemieślników, drudzy trudnią się handlem i tworzą klasę drobnomieszczaíską po miasteczkach.

Włościaństwo polskie zamieszkuje w zwartej masie przeważnie środkową część naszego kraju między Włodzimierzem i Uściługiem, która stanowi mniej więcej $2 / 5$ całego obszaru; na tej przestrzeni przedstawia obecnie mniej więcej $70 \%$ całej ludności, na południu i północy pomieszane jest przeważnie z ludnością ruską.

Polska większa własność ziemska (vide rosyjskie statystyki do Ziemstw ${ }^{13}$ 1909 r.) stanowi przeszło $60 \%$ całej tej własności, pozostałe, około $40 \%$, było w posiadaniu rosyjskich urzędników, którzy w majątkach swych nigdy nie mieszkali i tym samym nie wywierali żadnego wpływu na społeczne lub gospodarcze życie kraju.

Oprócz wzmiankowanej ludności wiejskiej posiadamy w miastach stan kupiecki i inteligencję miejską, która obecnie po wyemigrowaniu urzędników rosyjskich przedstawia jedyną tylko warstwę kulturalną.

13 Chodzi o samorządowe instytucje w paístwie rosyjskim. 
Następnie ludność polska przedstawia najważniejszą siłę autonomiczną kraju: wszystkie rodzaje przemysłu, szczególniej związanego z rolnictwem, jako to gorzelnictwo, browarnictwo, przemysł leśny, młynarstwo były i są całkowicie tylko w jej ręku. Wszelkie zrzeszenia gospodarcze i ekonomiczne, towarzystwa rolnicze, syndykaty rolnicze, kooperatywy rolne przed wojną były tu jedynie polskie.

Co najważniejsze. Polacy stanowili i stanowią jedyny naprawdę uświadomiony element narodowościowy o określonych dążeniach narodowych, społecznych i politycznych, czego stosować nie można do dwóch pozostałych elementów: Rusinów i Żydów.

Pierwsi (Rusini), chociaż dość liczni w północnej części kraju przedstawiają zupełnie inertną masę: przywiązani jedynie do prawosławia, uważali się przed wojną za Rosjan, czego najlepszy dali dowód, emigrując gremialnie na wschód razem $\mathrm{z}$ armią rosyjską $\mathrm{w} 1915 \mathrm{r}$. i zostawiając na laskę losu swe sadyby i cały dobytek w przeciwieństwie do ludności polskiej.

Żydzi, osiadli po miastach i miasteczkach, jak i wszędzie, nie wychodzą spoza ram krańcowego oportunizmu i przystosowania się do zewnętrznych warunków.

Polacy więc w tym kraju, jak byli, tak i są jedynym tu państwowo twórczym elementem, jedynym kośćcem wszelkiej organizacji społecznej i paílstwowej.

Najlepszy dowód, że z chwilą opuszczenia przez Rosjan kraju tego, kiedy nastąpiła możność jakiejś uprawnionej i jawnej organizacji społecznej u nas, wszystkie stowarzyszenia, które powstały, jako to: Komitet Obywatelski Powiatu Włodzimierskiego, Komitet Chrześcijański Miasta Kowla, Polska Macierz Szkolna z całym szeregiem kół miejscowych, Rzymsko-Katolickie Stowarzyszenie Dobroczynności we Wlodzimierzu - są to instytucje czysto polskie; w tej chwili, po ustąpieniu wojsk rosyjskich, zaczęły powstawać szkoły polskie, w bardzo wielu wypadkach samorzutnie organizowane przez włościan; dziś jest ich już prawie sześćdziesiąt, gdzie uczy się z górą 4 tysiące polskich dzieci.

Podnieść należy następnie jeszcze jedno ogromne znaczenie okupowanej części Wołynia, mianowicie znaczenie strategiczne.

Rosja poza Królestwem Polskim (Kongresowym), które miało specyficzny system fortec i kolei strategicznych, posiadała jako pierwszą linię obronną i jednocześnie wypadową od strony Królestwa Polskiego i Galicji system kolejowo-forteczny: Brześć Litewski - Kowel - Luck - Równe - Dubno ze specjalnymi odnogami strategicznymi, jak na przykład do Włodzimierza, 
gdzie ostatnimi czasy, przed samą wojną rząd rosyjski zamierzał również urządzic: fortecę.

Pozostawienie więc w ręku Rosji węzła kolejowego kowelskieggo i powstałego już w czasie wojny węzła włodzimierskiego i nie zrobienie wyłomu w tym systemie wypadowym rosyjskim, dałoby nowo powstające państwo polskie na łaskę i niełaskę Rosji pod względem strategicznym. Zresztą już nie raz powagi wojskowe Austro-Węgier i Niemiec zwracały na to uwagę, że Bug nie jest żadną granicą strategiczną i można jej szukać jedynie w jednym z dopływów Prypeci (Stochód lub Styr), przechodzącym przez bagna pińskie.

Tak więc śmiemy twierdzić stanowczo, że ze względu na prawa historyczne, na obecny stan posiadania, zaludnienia, uświadomienia narodowego, przede wszystkim zaś ze względu na przewagę kultury polskiej i zdolności państwowo-twórczej autochtonicznej ludności polskiej, jak również na ograniczone znaczenie strategiczne okupowanego Wołynia, kraj ten ma niezaprzeczone prawo domagania się przyłączenia do państwa polskiego.

Tym pewniejsza jest ludność polska spełnienia swych pragnień należenia do państwa polskiego, że część Wołynia, o której mowa, jest w posiadaniu wojsk austro-węgierskich, mocarstwa, które dziś ujęło w swe ręce stworzenie niepodległej i zjednoczonej Polski ${ }^{14}$.

CPHAU we Lwowie, fond 717, opis 1, sprawa 15, s. 61-64.

\section{Dokument nr 10}

1918 styczeń 16, Krosno. -- Uchwaly lokalnego kola Ligi Niezawislości Polski w Krośnie zawierajqce postulaty dotyczqce przylqczenia do powstajqcego państwa polskiego Galicji, Ślqska [Cieszyńskiego] i Poznańskiego.

Na zgromadzeniu Koła miejscowego Ligi Niezawisłości Polski w Krośnie dnia 16 stycznia 1918 r. zapadły następujące uchwały, które Zarządowi Głównemu celem przedłożenia Kołu Polskiemu przesyłamy ${ }^{15}$.

14 Pod memoriałem brak podpisu, a na marginesie znajduje się odręczny zapis w języku niemieckim: „Polnische Theil von Wołyn”.

15 Analogiczne uchwały zapadały w licznych miastach Galicji i są zachowane w tej samej jednostce archiwalnej, co postanowienia krośnieńskie. 
I

Liga Niezawisłości Polski stwierdzając, że stoi niezłomnie na stanowisku uchwały Koła Sejmowego z dnia 28 maja 1917 r. wyraża nadzieję, że kongres pokojowy $\mathrm{z}$ udziałem Polski załatwi ostatecznie sprawę granic niepodległego, suwerennego paístwa polskiego w duchu jednomyślnych dążeń narodu polskiego do zjednoczenia i niezawisłości.

Liga Niezawisłości Polski stwierdza, że wolą Polaków z zaboru austriackiego jest jak najszybsze przyłączenie Galicji i Śląska do niepodległego państwa polskiego jako pierwszego etapu zjednoczenia trzech zaborów.

Liga Niezawisłości Polski zastrzega się, że o formie rządu państwa polskiego rozstrzygać może tylko polski sejm ustawodawczy.

II

Zebrani wyrażają przekonanie, że stanowieniu o przyszłości Polski powinna wziąć udział zarówno Galicja i Śląsk, jak i Poznańskie i żądają imieniem szerokich kół obywatelskich udziału przedstawicieli Galicji w konstytuancie warszawskiej.

Koło miejscowe Ligi Niezawisłości w Krośnie.

Sekretarz St. Ciepielanka

Przewodniczący dr A. Jasiński

CPHAU we Lwowie, fond 717, opis 1 , sprawa 15, s. 40.

\section{Dokument nr 11}

1918, luty 10, Stryj. - Protest Polaków powiatów stryjskiego i skolskiego przeciw agitacji na rzecz wydzielenia Galicji wschodniej i środkowej z ogólnych obszarów galicyjskich.

Polacy powiatu stryjskiego i skolskiego przyłączają się w zupełności do rezolucji uchwalonej na wniosek ekscelencji [Stanisława] Głąbińskiego na wiecu odbytym we Lwowie ( "Ilust rowany Kurier Codzienny” nr 12, niedziela 13 stycznia).

Rezolucja ta brzmi.

„Wobec agitacji rozwiniętej w Galicji środkowej i wschodniej za oderwaniem części kraju od całości Galicji, tudzież wobec analogicznego programu galicy jskiego stronnictwa ukraińskiego, obywatele stołecznego miasta 
Lwowa stwierdzają, ie cała Galicja zostaje przyłączona do Austrii jako integralna część historycznej Polski i przez szereg wieków nieprzerwanie do Polski należała. Gdy nadto w całym kraju ludność polska tworzy niewątpliwą większość, a takìe stolica kraju Lwów ma niewątpliwie polski charakter, obywatele Lwowa domagają się, aby przy rokowaniach pokojowych zapewniono przywrócenie dawnej politycznej łączności całej Galicji z niepodległą, zjednoczoną Polską i aby pozostawiono przyszłym układom wolnej Polski z wolnymi sąsiednimi narodami rozgraniczenie obszarów narodowych przy zabezpieczeniu narodów i interesów mniejszości narodowych" ${ }^{16}$.

CPHAU we Lwowie, fond 717, opis 1, sprawa 15, s. 121.

\section{Dokument nr 12}

1918 kwiecień 26, Kraków. - Adres Komisji Litewskiej w Warszawie i Komitetu Wileńskiego skierowany do prezydium parlamentarnego Kola Polskiego $w$ Wiedniu o zagrożeniu możliwości przylqczenia Wileńszczyzny do przyszlego państwa polskiego.

Załączamy przy niniejszym memoriał tyczący się sprawy polskiej na Litwie i prosimy Świetne Prezydium o rozważenie poruszonych w nim spraw przy omawianiu całokształtu spraw polskich.

Kierownik Litewskiego Biura Informacyjnego Marian Świechowski

Członek Komisji Litewskiej w Warszawie i Komitetu Wileńskiego D. Jamoguniewski.

\section{Załącznik nr 1 .}

Rozbiór ziem Wielkiego Księstwa Litewskiego.

Rozbiór ziem Wielkiego Księstwa Litewskiego rozpoczęty traktatem pokojowym z 9 lutego [1918 w Brześciu Litewskim] pomiędzy państwami centralnymi a Ukrainą, został wykonany w dniu 3 marca [1918 w Brześciu Litewskim] na mocy traktatu pomiędzy tymi państwanni a Rosją.

Na mocy umów zawartych między rozbiorczymi państwami zostały ziemie Wielkiego Księstwa Litewskiego rozdarte na części. Cały południowy pas w obrębie dorzecza Prypeci, wynoszący 64412 kilometrów kwadrato-

16 Przy tekście lwowskiej uchwały kilka tysięcy podpisów. 
wych został zaanektowany na rzecz krystalizującego się jeszcze nie uświadomionego dostatecznie w stosunku do samego siebie tworu ukraińskiego. Jakkolwiek granica traktatowa została wytyczona wyraźnie tylko w północnej części powiatu brzeskiego poprzez Prużany do jeziora Wyganowskiego, to jasne jest, że w tym samym kierunku będzie przedłużona i dalej na wschód, odcinając wszystkie południowe powiaty $\mathrm{w}$ dolinie Prypeci. Zabór więc ten obejmowałby powiaty: Brześć, Kobryí, dwie trzecie powiatu Prużany, powiaty Pińsk, jedna trzecia słuckiego, Mozyr, Rzeczycę i Homel. Ludność rusińska, tak zwani „Poleszucy”, szczep kulturalnie ciążący ku Białorusinom, a gospodarczymi interesami związany z całością obszaru Księstwa Litewskiego, skupieni są tu tylko w trzech południowo-zachodnich powiatach, wynosząc około dwustu kilkudziesięciu tysięcy, gdy ludność białoruska tworzy na tej przestrzeni masę przekraczającą milion [osób].

Ludność polska na tym odciętym obszarze wynosi około 370 tysięcy i skupiona jest więcej w zachodniej części dochodząc do $30 \%$ w stosunku do innych chrześcijan ${ }^{17}$.

Połać wschodnia Wielkiego Księstwa [Litewskiego], składająca się częściowo z obszarów etnograficznie polskich, częściowo białoruskich i łotewskich, została zostawiona Rosji. Polacy mają przewagę tutaj na Zachodzie, Białorusini na wschodzie, Łotysze w północno-zachodnim kacie. Cały ten obszar wynosi 160 tysięcy kilometrów kwadratowych i obejmuje powiaty: Dzisna, Wilejka, połowa święciańskiego, Oszmiana, Mińsk, dwie trzecie słuckiego i Nowogródek (ziemia z większością polską); dalej powiaty białoruskie: Słonim, Bobrujsk, Ihumeń, gubernia mohylewska bez powiatu homelskiego i gubernia witebska bez wąskiego pobrzeża nad Dźwiną z miastem Dyneburgiem.

Trzy zachodnie powiaty guberni witebskiej stanowią katolicki obszar łotewski. Polacy na całej tej przestrzeni wynoszą około dwóch milionów, Białorusini prawosławni około trzech i pół miliona, Łotysze około 350 tysięcy.

Resztą - 79 tysięcy kilometrów kwadratowych oddano pod bezpośrednie wpływy Niemiec. Są to ziemie na północy etnograficznie litewskie (gubernia kowieńska i wąski przylegający pas guberni wileńskiej - razem czterdzieści kilka tysięcy kilometrów kwadratowych (na południu i w części środkowej ziemie etnograficznie polskie razem z Wilnem, obejmujące podług linii po-

17 W tekście doszło do użycia określenia „chrześcijan”, ponieważ autorzy pomijają obecność Żydów oraz osób wyznania muzułmaískiego, a zapewne także innych. 
działu powiaty: Wilno, połowę święciańskiego, znaczną część trockiego, powiaty Lida, Grodno, Wołkowysk, Sokółka. Białystok i Bielsk. Włączono tu i część północną powiatu prużariskiego, posiadającego już większość białoruską.

Jak już zaznaczaliśmy nie raz, cały kompleks ziem Wielkiego Księstwa Litewskiego, spojony tradycją sześćsetletniej wspólnej państwowości, pomimo różnic etnicznych, przesiąknięty wspólnym obyczajem i z polskiej kultury swoje oblicze duchowe biorący, przedstawia jednotę ${ }^{\mathrm{I}} \mathrm{g}$ gospodarczą, uwarunkowaną właściwościami przyrodniczymi klimatu oraz konfiguracjami terenu, spojoną całym systemem wód rzecznych, wśród skomplikowanych i krzyżujących się interesów rozmaitych grup narodowościowych nie da się tutaj wydzielić z kompleksu całości żadna część bez szkody tychże interesów którejkolwiek narodowości. A cóż dopiero mówić o podziale tak dowolnym i godzącyın wprost w najżywotniejsze interesy wszystkich ludów, jak podział dokonany przez traktaty brzeskie. Jedyną myślą przewodnią tych traktatów było przede wszystkim zniszczenie siły odpornej żywiołu polskiego i obezwładnienie żywiołu białoruskiego.

Zwarty obszar polski, rozpostarty między Kownem a Mińskiem i Podlasiem a wschodnią granicą guberni wileńskiej, obejmuje w granicach Wielkiego Księstwa. nie licząc guberni suwalskiej, 77 tysięcy kilometrów kwadratowych, a więc tyle prawie, co Galicja. Ludność polska wynosi tu przeciętnie około $60 \%$ w stosunku do chrześcijan, dochodząc, jak na przykład w obszarze wileńskim do $20 \%$ według spisów urzędowych niemieckich. Cały ten obszar traktatem brzeskim został rozdarty wzdłuż osi swojej podłużnej w kierunku z północnego wschodu ku południowemu zachodowi na dwa wąskie pasma. Pas włączony w obręb wpływów niemieckich (połowa guberni wileńskiej i pięć północno-zachodnich powiatów guberni grodzieńskiej) wynosi 37483 tysiące kilometrów kwadratowych z 1069951 ludności polskiej. Druga połowa obszaru polskiego, wynosząca 37281 tysięcy kilometrów kwadratowych (druga połowa guberni wileńskiej i część guberni mińskiej) z 854438 [osobami] ludności polskiej pozostała przy Rosji. Część powiatu słuckiego, również o większości polskiej, jak już wspominaliśmy sądząc z kierunku wytyczenia granicy ukraińskiej, dostanie się Ukrainie.

Aneksja południowych obszarów, dokonana na rzecz Ukrainy, ostrzem swym skierowaną została głównie przeciw Białorusinom usuwając możliwość porozumienia się między sobą tych pobratymczych szczepów. Pomijając od-

18 Tak $w$ tekście. 
danie jednego miliona Białorusinów pod władzę ukraińską, odcięcie głównej spławnej drogi wodnej, wiodącej kı Morzu Czarnemı, jest ruiną ekonomiczną dla południowych obszarów pod względem zaśs strategicznym czyni je zupełnie bezbronnymi i od państwa ukraińskiego uzależnionymi.

Zamiast możliwości pokojowego współżycia traktaty brzeskie stwarzają zarzewie wiecznych walk w przyszłości. Stwarzają węzeł nieporównanie gorszy niż Bałkany. Jedynie neutralizacja całego kompleksu ziem Wielkiego Księstwa [Litewskiego] jako federacyjnego związku poszczególnych ludów na wzór Szwajcarii mogłaby w warunkach obecnych całemu krajowi zapewnić pokój i rozwój szczęśliwy. Usunęłaby w ten sposób rywalizację państw ościennych o wyłączne wpływy zadość czyniąc: uprawnionym interesom wszystkich bez uprzywilejowania czyichkolwiek. Federacyjna forma ustroju zapewniłaby jak najszerszy rozwój przejawom wszelkich indywidualizınów szczepowych. Paŕstwo polskie, które specjalnie zainteresowane w sprawiedliwyın rozwiązaniu problematu ziem litewskich tylko $\mathrm{z}$ tym ostatnim rozwiązaniem pogodzić by się nogło, wszelkie inne będąc zmuszone uważać za skierowane również i przeciwko sobie.

Załącznik nr 2.

Do Świetnego Prezydium Koła Polskiego w Wiedniu.

Sprawa polska a rozwój ziem Wielkiego Księstwa Litewskiego na mocy traktatów brzeskich.

Dotychczas pod względem politycznym zwrócono uwagę głównie i zareagowano na jedną stronę traktatów brzeskich, mianowicie tę, która bezpośrednio dotknęła Królestwo [Polskie] przez przyznanie Ukrainie Chełmszczyzny i zagroziła przez to całości Galicji. Jednakże dla całokształtu sprawy polskiej równie w skutki groźną jest i ta strona, która jakkolwiek nie godząc bezpośrednio Polskę, dokonała rozbioru ziem Wielkiego Księstwa Litewskiego.

Mocą pierwszego traktatu zawartego z Ukrainą zostało od Wielkiego Księstwa Litewskiego oderwane całe Polesie z dorzeczem Prypeci, mocą traktatu drugiego, zawartego z Rosją został rozdarty na dwie części obszar pozostały.

Traktaty te godzą przede wszystkim w najżywotniejsze interesy trzymilionowego narodu polskiego zamieszkałego na Litwie.

Oderwanie Polesia godzi w jego interesy ekonomiczne odcinając spławną drogę wodną ku Morzu Czarnemu, jaką jest Prypeć.

Przeprowadzenie granicy podziałowej z Rosją nie tylko rozbija w dalszym ciągu jednolity obraz ekonomiczny tych ziem, godząc w interesy wszystkich ludów, ale przede wszystkim najfatalniej rozrywa na dwie części 
zwarty obszar ziem polskich na Litwie między Kownem a Mińskiem, obszar co do przestrzeni równy niemal całej Galicji, a co do polskości nie ustępujący wcale Chełmszczyźnie.

Granica ta, przepoławiająca zwarty kompleks ziem polskich na Litwie, przenoszący więcej niż dwukrotnie Belgię, niszczy zupełnie siłę i jedność elementu polskiego na ziemiach litewskich i jest ciosem dla całokształtu interesów Polski nie mniej dotkliwym niż zabór Chełmszczyzny.

Powstające paístwo polskie zainteresowane jest w normalnym rozwoju elementu polskiego na ziemiach graniczących na wschodzie, zainteresowane jest w zgodnym, nie dającym powodu do tarć, uregulowania spraw tam poszczególnych narodowości.

Traktaty brzeskie, niszcząc podstawy rozwoju na ziemiach litewskich elementu polskiego, poddając go hegemonii innych ludów, stwarzając źródło wiecznych tarć i zamieszek, zmuszających przyszłe państwo polskie do interwencji i zdolnych zakłócić na nowo przyszły pokój europejski.

Linia podziałowa przeprowadzona na mocy umowy z Rosją, oprócz rozbijania jednolitego obszaru polskiego, rozbija również obszar z przewagą katolicyzmu na wschodzie. Linia rozgraniczająca obszary o przewadze prawosławia i katolicyzmu, przebiegająca mniej więcej wododziałem rzek Dniepru i Berezyny w kierunku z północy na południe, a linia podziałowa obecna przebiega ukośnie, oddając znaczne obszary z większością katolicką pod hegemonię prawosławia, jest dokonaną wbrew interesom Kościoła katolickiego przy współudziale państwa tak wybitnie katolickiego, jak Austria.

Ponieważ na plenarnym posiedzeniu Koła Polskiego w dniu 1 maja ma być rozważany całoksztalt spraw polskich w związku z traktatami brzeskimi, pożądanym by było, żeby powyższe uwagi mogły być poddane pod rozwagę plenum, było by pożądane, żeby odpowiednie wnioski i rezolucje mogły być zgłoszone przy omawianiu traktatów brzeskich w komisji delegacyjnej dla spraw zagranicznych.

W równocześnie załączonej notatce statystycznej ${ }^{19}$, tyczącej się rozbioru ziem Wielkiego Księstwa Litewskiego przytoczone cyfry mogą być podane w formie bardziej szczegółowej.

Kraków, dnia 26 kwietnia 1918 r.

CPHAU we Lwowie, fond 717, opis 1, sprawa 15, s. 261-266.

19 Przy publikowanych dokumentach notatki takiej nie ma. 